\title{
Status of Heavy Metal in the Lower Gangetic Delta: Implication of Acidification on Compartmentation
}

\author{
Abhijit Mitra $^{1^{*}}$, Sufia Zaman ${ }^{1}$, Harekrishna Jana ${ }^{2}$, Tanmay Ray Chaudhuri ${ }^{3}$, Gahul Amin ${ }^{4}$, U.K. De ${ }^{5}$ and Somnath Das ${ }^{5}$ \\ ${ }^{1}$ Department of Marine Science, University of Calcutta, 35, Ballygunge Circular Road, Kolkata, India \\ ${ }^{2}$ Department of Microbiology, Panskura Banamali College, Purba Medinipur, India \\ ${ }^{3}$ Department of Forest and Environmental Science, Techno India University, Salt Lake Campus Kolkata, India \\ ${ }^{4}$ Department of Physics, Chanchal College, Malda, India \\ ${ }^{5}$ School of Environmental Studies, Jadavpur University, Kolkata, India
}

*Corresponding author: Abhijit Mitra, Department of Marine Science, University of Calcutta, 35, B.C. Road, Kolkata 700 019 (W.B), India, Tel: 09831269550; E-mail: abhijit_mitra@hotmail.com

Rec date: Mar 16, 2014; Acc date: Apr 10, 2014; Pub date: Apr 12, 2014

Copyright: (c) 2014 Mitra A, et al. This is an open-access article distributed under the terms of the Creative Commons Attribution License, which permits unrestricted use, distribution, and reproduction in any medium, provided the original author and source are credited.

\begin{abstract}
Increased atmospheric carbon dioxide concentrations are causing greater dissolution of carbon dioxide into the estuarine water, which is the key factor behind today's ongoing ocean acidification and subsequent compartmentation of heavy metals in the system. We conducted a long term survey on temporal variation of $\mathrm{pH}$ and its impact on heavy metals in the Matla estuary, situated in the central part of Indian Sundarbans. The present study indicates the key role of acidification (major driver) in the exchange of heavy metals from sediment compartment to the overlying aquatic phase. The lowering of $\mathrm{pH}$ favours the process of dissolution of selected heavy metals $(\mathrm{Zn}, \mathrm{Cu}$ and $\mathrm{Pb}$ ) and promotes the transference of metallic compounds from the sediment to the aquatic phase.
\end{abstract}

Keywords: Acidification; Surface water pH; Dissolved heavy metals; Biologically available heavy metals in the sediment

\section{Introduction}

Over the last century, the atmospheric concentration of carbon dioxide has risen at a rate 100 times faster than any change observed during the past 650,000 years [1]. There is broad consensus that this ongoing change is a direct result of human activity, principally by fossil fuel burning, cement production and changing land use [2]. Atmospheric levels of carbon dioxide have consequently increased from pre-industrial levels of $280 \mathrm{ppm}$ to a concentration of approximately $380 \mathrm{ppm}$ [3]. Almost $50 \%$ of all anthropogenic carbon dioxide emitted to the atmosphere has diffused passively into the ocean, thereby significantly decreasing the rate of global warming [4]. Concentrations of atmospheric carbon dioxide are rising at a rate of $3.3 \%$ per year and will continue this rising trend [5]. Hydrological models predict that, based on proposed future emissions of carbon dioxide, the average oceanic $\mathrm{pH}$ will decline by $0.3-0.5$ by the year 2100 and by 0.7 within the next 300 years [6]. Leakage from carbon dioxide seabed storage would create locally faster and stronger acidification than that induced by atmospheric carbon dioxide [7].

On the basis of the global trend of acidification, we try to focus on the issue at the local level in the Matla River situated in the central Indian Sundarbans of the lower Gangetic delta region and evaluate the role of the phenomenon on the compartmentation of selected heavy metals $(\mathrm{Zn}, \mathrm{Cu}$ and $\mathrm{Pb})$, that are dominant in the present geographical locale $[8,9]$.

\section{Materials and Methods}

\section{Study area}

The lower Gangetic delta region, at the apex of Bay of Bengal sustains the famous mangrove dominated ecosystem, the Sundarbans. The central part of the delta complex receives the water of the Matla River. Industries are almost absent along the bank of the river, but the water is contaminated with sewage from the highly urbanized city of Kolkata. Reports of considerable concentrations of $\mathrm{Zn}, \mathrm{Cu}$ and $\mathrm{Pb}$ are also available in this region, which originates mainly from the antifouling paints used for conditioning the fishing vessels and trawlers [8-12]. The present study was conducted $1.5 \mathrm{~km}$ off Bonnie camp $\left(21^{\circ} 49^{\prime} 42.9^{\prime \prime} \mathrm{N} / 88^{\circ} 37^{\prime} 13.7^{\prime \prime} \mathrm{E}\right)$ in the Ajmalmari river (local name) that receives the water from the Matla River.

\section{Measurement of aquatic $\mathrm{pH}$}

$\mathrm{pH}$ of the surface water in the selected sampling station was measured during high tide condition with a portable $\mathrm{pH}$ meter (sensitivity $= \pm 0.02$ ).

\section{Analysis of dissolved $\mathrm{Zn}, \mathrm{Cu}$ and $\mathrm{Pb}$}

Surface water samples were collected from the sampling station using $10^{-1}$ Teflon-lined Go-Flo bottles, fitted with Teflon taps and deployed on a rosette or on Kevlar line, with additional surface sampling carried out by hand. Shortly after collection, samples were filtered through Nuclepore filters $(0.4 \mu \mathrm{m}$ pore diameter $)$ and aliquots of the filters were acidified with sub-boiling distilled nitric acid to a $\mathrm{pH}$ of about 2 and stored in cleaned low-density polyethylene bottles. Dissolved heavy metals were separated and pre-concentrated from the seawater using dithiocarbamate complexation and subsequent 
Citation: Mitra A, Zaman S, Jana H, Chaudhuri TR, Amin G, et al. (2014) Status of Heavy Metal in the Lower Gangetic Delta: Implication of Acidification on Compartmentation. J Environ Anal Chem 1: 111. doi:10.4172/jreac.1000111

Page 2 of 4

extraction into Freon TF, followed by back extraction into $\mathrm{HNO}_{3}$ as per the procedure of Danielsson et al. [13]. Extracts were analyzed for $\mathrm{Zn}, \mathrm{Cu}$ and $\mathrm{Pb}$ by Atomic Absorption Spectrophotometer (Perkin Elmer: Model 3030). The accuracy of the dissolved heavy metal determinations is indicated by good agreement between our values and reported for certified reference seawater materials (CASS 2) (Table 1a).

\begin{tabular}{|l|l|l|}
\hline Element & Certified value $\left(\mu \mathrm{g} \mathrm{I}^{-1}\right)$ & Laboratory results $\left(\mu \mathrm{g} \mathrm{I}^{-1}\right)$ \\
\hline $\mathrm{Zn}$ & $1.97 \pm 0.12$ & $2.01 \pm 0.14$ \\
\hline $\mathrm{Cu}$ & $0.675 \pm 0.039$ & $0.786 \pm 0.058$ \\
\hline $\mathrm{Pb}$ & $0.019 \pm 0.006$ & $0.029 \pm 0.009$ \\
\hline
\end{tabular}

Table 1a: Analysis of reference material for near shore seawater (CASS 2)

\section{Analysis of biologically available $\mathrm{Zn}, \mathrm{Cu}$ and $\mathrm{Pb}$}

Sediment samples from surface $(1 \mathrm{~cm}$ depth) were collected by scrapping using a pre-cleaned and acid washed plastic scale and immediately kept in clean polythene bags, which were sealed. The samples were washed with metal free double distilled water and dried in an oven at $105 \mathrm{oC}$ for 5-6 hours, freed from visible shells or shell fragments, ground to powder in a mortar and stored in acid washed polythene bags. Analyses of biologically available metals were done after re-drying the samples, from which $1 \mathrm{gm}$ was taken and digested with $0.5(\mathrm{~N}) \mathrm{HCl}$ as per the standard procedure outlined by Malo [14]. The resulting solutions were then stored in polythene containers for analysis. The solutions were finally aspirated in the flame Atomic Absorption Spectrophotometer (Perkin Elmer: Model 3030) for the determination of metal concentrations. No detectable trace metals were found in the reagent blank. Analysis of the NIES Sargasso sample was carried out to assure the quality of the data (Table $1 \mathrm{~b}$ ).

\begin{tabular}{|l|l|l|}
\hline Element & Certified value $\left(\mu \mathrm{g} \mathrm{g}^{-1}\right)$ & Laboratory results $\left(\mu \mathrm{g} \mathrm{g}^{-1}\right)$ \\
\hline $\mathrm{Zn}$ & 28.6 & 26.2 \\
\hline $\mathrm{Cu}$ & 14.9 & 13.7 \\
\hline $\mathrm{Pb}$ & 2.4 & 2.9 \\
\hline
\end{tabular}

Table 1b: Analysis of reference material (NIES Sargasso sample) for sediments obtained from the National Institute of Environmental Studies, Japan

\section{Statistical analysis}

Inter-relationships between aquatic $\mathrm{pH}$, selected dissolved heavy metals and biologically available heavy metals in sediment were determined through correlation coefficient values, scatter plots and allometric equations for all possible combinations. All statistical calculations were performed with SPSS 9.0 for Windows.

\section{Results}

\section{Surface water $\mathrm{pH}$}

The surface water $\mathrm{pH}$ exhibited variation within a small range. Highest value was recorded during 1985 (8.32) and lowest value (8.29) was recorded during 2013 (Figure 1). The gradual lowering of $\mathrm{pH}$ $(0.001 / \mathrm{yr})$ clearly confirms the phenomenon of acidification in the Matla estuarine system.

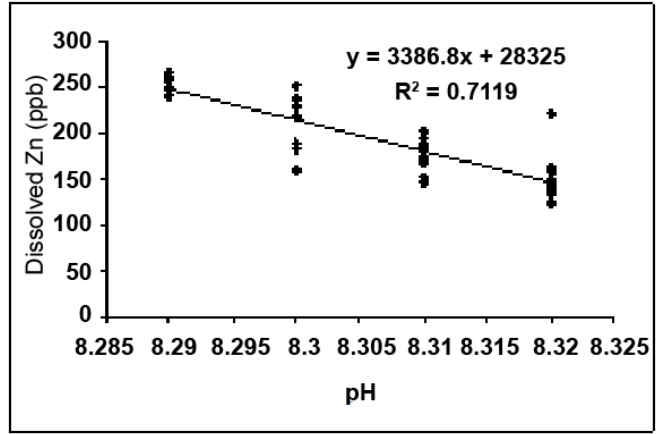

Figure 1: Inter-relationship between dissolved $\mathrm{Zn}$ and $\mathrm{pH}$

\section{Dissolved metal}

The order of dissolved heavy metals in the estuarine water is $\mathrm{Zn}>\mathrm{Cu}>\mathrm{Pb}$. Dissolved $\mathrm{Zn}$ ranged from $123.66 \mathrm{ppb}$ during (1984) to $265.00 \mathrm{ppb}$ during (2013) (Figure 2). Dissolved $\mathrm{Cu}$ ranged from 44.75 ppb during (1984) to $97.14 \mathrm{ppb}$ during (2013) (Figure 3). During the study period the value of dissolved $\mathrm{Pb}$ ranged from $7.39 \mathrm{ppb}$ (1984) to $17.39 \mathrm{ppb}$ (2013). All the selected dissolved metals thus exhibit an increasing trend.

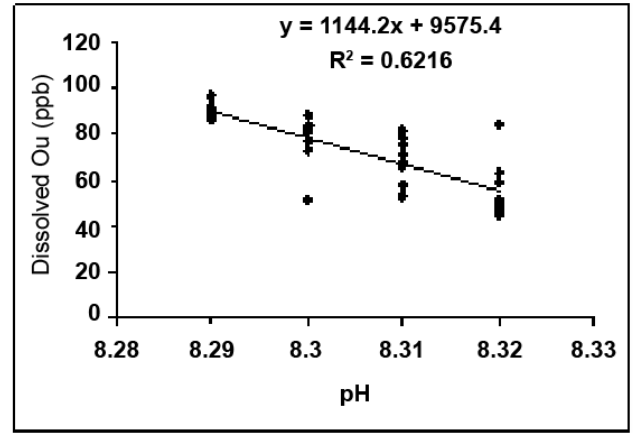

Figure 2: Inter-relationship between dissolved $\mathrm{Cu}$ and $\mathrm{pH}$ 
Citation: Mitra A, Zaman S, Jana H, Chaudhuri TR, Amin G, et al. (2014) Status of Heavy Metal in the Lower Gangetic Delta: Implication of Acidification on Compartmentation. J Environ Anal Chem 1: 111. doi:10.4172/jreac.1000111

Page 3 of 4

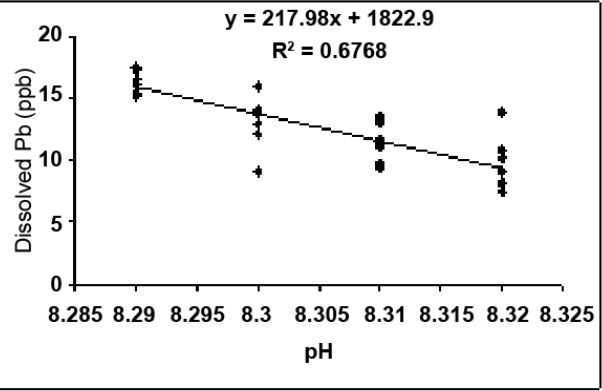

Figure 3: Inter-relationship between dissolved $\mathrm{Pb}$ and $\mathrm{pH}$

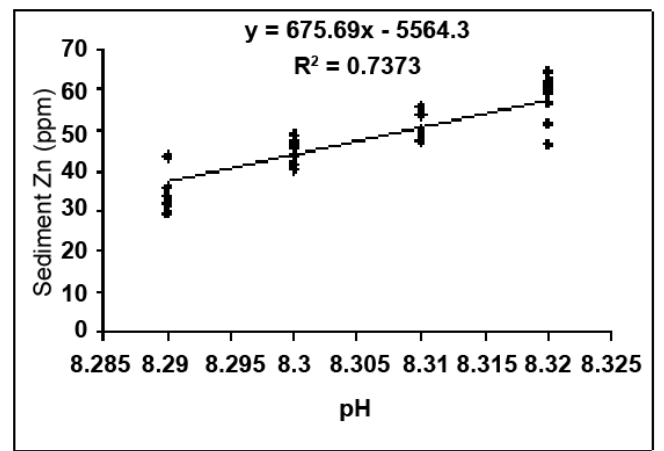

Figure 4: Inter-relationship between sediment $\mathrm{Zn}$ and $\mathrm{pH}$

\section{Sediment metal}

In sediment compartment, the biologically available metals exhibited a decreasing trend. In case of $\mathrm{Zn}$, the value decreased from $64.71 \mathrm{ppm}$ (during 1984) to $29.66 \mathrm{ppm}$ (during 2013). In case of $\mathrm{Cu}$, the value ranged from $7.31 \mathrm{ppm}$ (during 2013) to $23.61 \mathrm{ppm}$ (during 1984). In case of $\mathrm{Pb}$, the lowest value was observed during 2013 (1.08 $\mathrm{ppm})$ and the highest value was recorded during $1984(10.78 \mathrm{ppm})$. It is also noted that the order of biologically available heavy metals in sediment is similar to that of dissolved heavy metals $(\mathrm{Zn}>\mathrm{Cu}>\mathrm{Pb})$.

\section{Discussion}

Ocean acidification is predicted to occur under current IPCC $\mathrm{CO}_{2}$ emissions scenarios [15]. Around 50\% of the emissions of carbon dioxide are being absorbed by the oceans, increasing the $\mathrm{pCO}_{2}$ with a concomitant decrease in the surface $\mathrm{pH}$ by $0.3-0.4$ units by the end of the century $[3,16,17]$. At present, the carbon dioxide interaction with seawater reduces the carbonate ion concentration, which is thought to regulate the calcification of extracellularly calcifying organisms $[18,19]$. This process is governed by the $\mathrm{CaCO}_{3}$ saturation state $(\Omega$ $\left.\left(\mathrm{CO}_{3}{ }^{2-}\right)\left(\mathrm{Ca}^{2+}\right) / \mathrm{K}^{\star} \mathrm{sp}\right)$, where $\mathrm{K}^{\star} \mathrm{sp}$ is the apparent stoichiometric solubility product. For values of $\Omega<1$ (undersaturated), seawater is corrosive, and dissolution may proceed [20]. The process triggers the rate of dissolution of precipitated heavy metals from the sediment compartment to the water column and alters the speciation of selected heavy metals in the study area. The scatter plots (Figures 1-6) explain the significant negative and positive relationships of aquatic $\mathrm{pH}$ with dissolved and biologically available heavy metals in surface sediments respectively.

The results suggest that heavy metal concentrations in coastal and estuarine waters need to be monitored considering the phenomenon of acidification, which is a major driver in altering the species of heavy metals in the coastal and estuarine ecosystem.

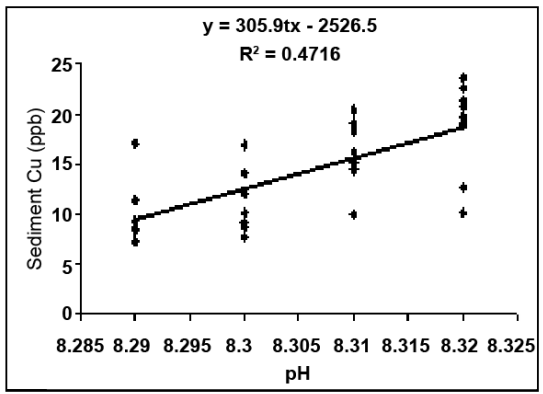

Figure 5: Inter-relationship between sediment $\mathrm{Cu}$ and $\mathrm{pH}$

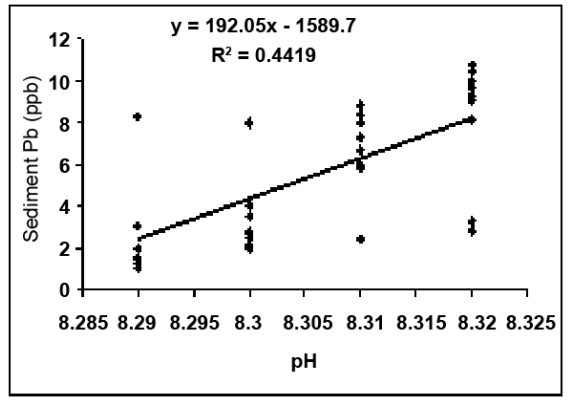

Figure 6: Inter-relationship between sediment $\mathrm{Pb}$ and $\mathrm{pH}$

\section{References}

1. Siegenthaler U, Stocker TF, Monnin E, Lüthi D, Schwander J, et al. (2005) Stable carbon cycle-climate relationship during the Late Pleistocene. Science 310: 1313-1317.

2. Hansen J, Sato M, Ruedy R, Kharecha P, Lacis A, et al. (2007) Dangerous human-made interference with climate: a GISS model E study. Atmos Chem Phys 7: 2287-2312.

3. Feely RA, Sabine CL, Lee K, Berelson W, Kleypas J, et al. (2004) Impact of anthropogenic $\mathrm{CO} 2$ on the $\mathrm{CaCO} 3$ system in the oceans. Science 305: 362-366.

4. Sabine CL, Feely RA, Gruber N, Key RM, Lee K, et al. (2004) The oceanic sink for anthropogenic CO2. Science 305: 367-371.

5. Canadell JG, Le Quéré C, Raupach M, Field CB, Buitenhuis ET, et al. (2007) Contributions to accelerating atmospheric CO2 growth from economic activity, carbon intensity, and efficiency of natural sinks. Proceedings of National Academy of Sciences, USA, 104: 18866-18870.

6. Caldeira K, Wickett ME (2003) Oceanography: anthropogenic carbon and ocean $\mathrm{pH}$. Nature 425: 365. 
Citation: Mitra A, Zaman S, Jana H, Chaudhuri TR, Amin G, et al. (2014) Status of Heavy Metal in the Lower Gangetic Delta: Implication of Acidification on Compartmentation. J Environ Anal Chem 1: 111. doi:10.4172/jreac.1000111

Page 4 of 4

7. Hawkins DG (2004) No exit: thinking about leakage from geologic carbon storages sites. Energy 29: 1571-1578.

8. Mitra A (1998) Status of coastal pollution in West Bengal with special reference to heavy metals. Journal of Indian Ocean Studies 5: 135-138.

9. Mitra A, Banerjee K, Sinha S (2011) Shrimp tissue quality in the lower Gangetic delta at the apex of Bay of Bengal. Toxicological \& Environmental Chemistry 93: 565-574.

10. Mitra A, Choudhury A, Zamaddar YA (1992) Effects of heavy metals on benthic molluscan communities in Hooghly estuary. Proceedings of Zoological Society, 45: 481-496.

11. Mitra A, Choudhury A (1993) Seasonal variations in metal content in the gastropod Nerita articulata (Gould). Indian Journal of Environmental Health, NEERI 35: 31-35

12. Mitra A, Mondal K, Banerjee K (2010) Concentration of heavy metals in fish juveniles of Gangetic delta of West Bengal, India. Research Journal of Fisheries and Hydrobiology 5: 21-26.

13. Danielsson LG, Magnusson B, Westerlund S (1978) An improved metal extraction procedure for the determination of trace metals in seawater by atomic absorption spectrometry with electrothermal atomization. Analytica Chimica Acta 98: 45-57.

14. Malo BA (1977) Partial extraction of metals from aquatic sediments. Environ Sci Technol 11: 277-282.
15. Houghton JT, Ding Y, Griggs DJ, Noguer M, Van der Linden PG (2001) Climate Change 2001: the scientific basis: contributions of Working Group I to the third assessment Report of the Intergovernmental Panel on Climate Change. Cambridge University Press, Cambridge, UK.

16. Caldeira K, Wickett ME (2005) Ocean model predictions of chemistry changes from carbon dioxide emissions to the atmosphere and ocean. Journal of Geophysical Research 110: C09S04.

17. Orr JC, Fabry VJ, Aumont O, Bopp L, Doney SC et al. (2005) Anthropogenic ocean acidification over the twenty-first century and its impact on calcifying organisms. Nature 437: 681-686.

18. Spero HJ, Bijma J, Lea DW, Bemis BE (1997) Effect of seawater carbonate ion concentration on foraminiferal carbon and oxygen isotopes. Nature 390: 497-500.

19. Marubini F, Ferrier-Pages C, Furla P, Allemand D (2008) Coral calcification responds to seawater acidification: a working hypothesis toward a physiological mechanism. Coral Reefs 27: 491-499.

20. Isaji S (1995) Defensive strategies against shell dissolution in bivalves inhabiting acidic environments: the case of Geloina (Corbiculidae) in mangrove swamps. Veliger 38: 2350-246. 